\title{
CAVITATIONAL INFLUENCE ON THE BACILLUS CEREUS BACTERIA AND OSCILLATORIA BREVIS CYANOBACTERIA
}

\author{
Iryna Z. Koval $^{1}$
}

${ }^{1}$ Department of General Chemistry, Lviv Polytechnic National University, Bandera str., 12, Lviv 79013, Ukraine. Email: irynazk@gmail.com

\begin{abstract}
Cavitation action has shown high efficiency of water purification of bacterial cells and cyanobacteria. The general and combined relative series of Bacillus cereus effective destruction in water medium under cavitational conditions in the gas atmosphere is: Ar/US > $\mathrm{O}_{2} / \mathrm{US}>\mathrm{He} / \mathrm{US}>\mathrm{CO}_{2} / \mathrm{US}$. It was detected mechanical destructions of the bacterial cells after 1 minute of sonication process and almost completely destroyed cyanobacteria after sonication time of 2-3 seconds. Destruction of bacterial cells is described by a kinetic reaction of the first order. Even short-term sonication of low intensity and low frequency leads to completely mechanical destruction of microorganisms. Bacterial cells after disaggregation retains morphological features and fully viable. But, despite this, B. cereus and Oscillatoria brevis have lost the ability of physiological generation of the cells and reproduction ability after cavitational treatment.
\end{abstract}

Keywords: Bacillus cereus, cavitation, cell destruction, Oscillatoria brevis, water purification.

\section{Introduction}

Cavitational phenomena are widely used in different spheres nowadays, especially as a water disinfection method [1, 2]. But there is not enough experimental data to create the scientific basis for the use of a cavitation in the processes of water purification of mıcroorganısms (MO) that requires a more detailed and in-depth study. According to our previous studies, an efficiency of natural water disinfection using cavitation alone was $86.5-88.3 \%$ [3], but efficiency of sewage disinfection from pharmaceutical enterprise durıng combıned actıon of gas of different nature and cavitatıon was 91.6$97.9 \%$ [3]. The highest efficiency $(97.9 \%)$ of sewage disinfection was achieved under Ar/US-action. Has been determıned an Intensification about $10 \pm 1 \%$ of sewage decontamination under the simultaneous gas/US action compared with the gas influence without cavitatıon (synergıstıc effect). Intensification of water disinfection under acoustic cavitation conditions indicates an importance and practical significance of proposed method in water technology. But treatment of natural water or sewage Indicates cavitation action on mixture of varıous MO types, but not on individual cells. That is why, this work devoted to study destruction of some bacteria type (B. cereus) sand cyanobacteria (O. brevis) under cavitational conditıons. Practical application of cavitational influence on the individual cells of will result in expansion of the opportunities and improve the water disinfection technology. 


\section{Materials and Methods}

The investigated water objects were the model microbial suspension infected by bacteria of Bacillus type and natural water, which contains blue-green algae (cyanobacteria). Model dispersion was prepared by adding pure cultures of bacterial cells into the deaerated distilled water with initial number of microorganisms $\left(\mathrm{NM}_{0}\right)$ of $8 \cdot 10^{2} \mathrm{CFU} / \mathrm{cm}^{3}$.

The source of cavitation generation was ultrasound (US) waves. Ultrasonic vibrations were transmitted by the magnetostriction radiator, immersed into the investigated water $\left(\mathrm{V}_{\mathrm{H} 2 \mathrm{O}}=75 \mathrm{~cm}^{3}\right)$. Experimental conditions were the following: sonication time 7200 $\mathrm{s}$ (for bacterial cells) and 60 seconds (for cyanobacteria) at the frequency of $22 \mathrm{kHz}$, intensity $\left(1.65 \mathrm{~W} / \mathrm{cm}^{3}\right)$, pressure $101.3 \mathrm{kPa}$, temperature $298 \pm 1 \mathrm{~K}$. As additional gases for the research oxygen, argon and carbon dioxide were used. Gases bubbled into the water during the whole process with the rate of $\sim 1 \mathrm{~cm}^{3} / \mathrm{s}$. The gas bubbling and US took place simultaneously in the same vessel.

Samples of sonicated water $\left(1 \mathrm{~cm}^{3}\right)$ were poured out in Petri dishes on a nutrient medium (meat water $\left(1 \mathrm{dm}^{3}\right)$, pepton $(10 \mathrm{~g})$, agar $(15 \mathrm{~g})$ ). NM were determined by the amount of colony forming units (CFU), which were grown in a Petri plates. Petri dishes were placed in TS-80M-3 thermostat at the temperature of $37^{\circ} \mathrm{C}$ for $48 \mathrm{~h}$. Water samples taken before US action served as the control samples. The concentration of microbial cells was determined by the number of colony forming units, assuming that each colony developed from a single cell.

Based on the range of microbiological tests the NM dynamics depending on the aqueous medium conditions and water sampling date was established. For this purpose, the samples of natural water were periodically taken from different natural sources during June and July.

Microorganisms identification was carried out by microscopic investigation using "crushed drop" preparations and fixed cells preparations with safranin as a coloring agent to study the morphological features of the cells. "Crushed drop" preparations mean the direct research of the water samples using the microscope. It was also investigated cultural [4] and physiological [5] features of domınant colonies.

\section{Results and Discussion}

\subsection{Bacillus cereus destruction}

The results of analysis of quantitative and qualitative composition of water microflora in different water objects were presented with the identification of the dominant kind of MO (Table 1), which were carried out during the summer period (June-July). Bacillus cells were selected for study as the most common type among bacillary bacteria, according to our microbial definition of contaminated water resources. 


\begin{tabular}{|c|c|c|}
\hline \multicolumn{3}{|c|}{ Dominating microflora of different waters } \\
\hline № & Water objects & Identified MO \\
\hline 1 & $\begin{array}{l}\text { lake (Lviv region, Sudova Vyshnya } \\
\text { city); } \mathrm{NM}_{0}=820 \div 2090 \mathrm{CFU} / \mathrm{cm}^{3}\end{array}$ & $\begin{array}{ll}\text { Bacterium, } & \text { Sarcina, } \\
\text { Bacillus }^{*}(35 \%) & \end{array}$ \\
\hline 2 & $\begin{array}{l}\text { lake (Lviv region, Gorodok city); } \\
\mathrm{NM}_{0}=2200 \div 2340 \mathrm{CFU} / \mathrm{cm}^{3}\end{array}$ & Staphylococcus, Pseudomonas, Bacillus*(40\%) \\
\hline 3 & $\begin{array}{l}\text { lake (Lviv region, Domazhyr } \\
\text { village); } \\
\mathrm{NM}_{0}=2100 \div 2600 \mathrm{CFU} / \mathrm{cm}^{3}\end{array}$ & $\begin{array}{l}\text { Bacterium, } \quad \text { Bacillus, } \\
\text { Pseudomonas }{ }^{*}(55 \%)\end{array}$ \\
\hline 4 & $\begin{array}{l}\text { lake (Lviv region, Myklashiv village); } \\
\mathrm{NM}_{0}=2450 \mathrm{KYO} / \mathrm{cm}^{3}\end{array}$ & $\begin{array}{l}\text { Bacterium, Pseudomonas, } \\
\text { Oscillatoria }(99 \%)\end{array}$ \\
\hline 5 & $\begin{array}{l}\text { "Navariya" lake (Lviv); } \\
\mathrm{NM}_{0}=1800 \div 2050 \mathrm{CFU} / \mathrm{cm}^{3}\end{array}$ & $\begin{array}{l}\text { Micrococcus, Sarcina, } \\
\text { Streptococcus, Bacillus } \text { Bacterium }^{\star}(29 \%) \text {, }\end{array}$ \\
\hline 6 & $\begin{array}{l}\text { WW of "Kumpel" brewery (Lviv); } \\
\mathrm{NM}_{0}=110000 \mathrm{CFU} / \mathrm{cm}^{3}\end{array}$ & $\begin{array}{l}\text { Micrococcus, Sarcina, Bacterium, } \\
\text { Pseudomonas, Bacillus }{ }^{\star}(25 \%) \\
\text { yeasts: Saccharomyces }(99 \%)\end{array}$ \\
\hline 7 & $\begin{array}{l}\text { WW of } \quad \text { "Halychfarm" } \\
\text { pharmaceutical plant (Lviv); } \mathrm{NM}_{0}= \\
38600 \mathrm{CFU} / \mathrm{cm}^{3}\end{array}$ & $\begin{array}{l}\text { Micrococcus, Diplococcus, } \\
\text { Sarcina, Bacterium, } \\
\text { Bacillus }{ }^{\star}(22 \%)\end{array}$ \\
\hline
\end{tabular}

Note: ${ }^{*}$ - in dominant amount.

Viability of B.cereus under the simultaneous gas/US action is presented in Fig. 1. As we see, this process can be divided on two stages. The first stage, unlike the second, describes the process of $N M$ increase in the system. During the first stage (duration of 180s) destruction of agglomerates occur, which were found of different forms in the initial samples of dispersion (Fig. $2 a-c$ ). Result of disaggregation process is the presence of smaller aggregates and single cells in the medium (Fig. $2 d$ ), that is an explanation of $N M$ increasing in it. Obviously, $N M$ increasing is directly proportional to the cells amount in the aggregates. Investigation of cells using microscopy indicated that they were morphologically normal after disaggregation. But, despite this, the cells have lost their ability to propagation because the cells on the division stage have not been found at that moment. It was additionally confirmed during short-term sonication of dispersion, in which have not any microbial agglomerates. In this case, NM enhancement has not been identified in the medium, i.e. disaggregation process, cells reproduction and propagation under the investigated US frequency, intensity and duration was not found in the liquid.

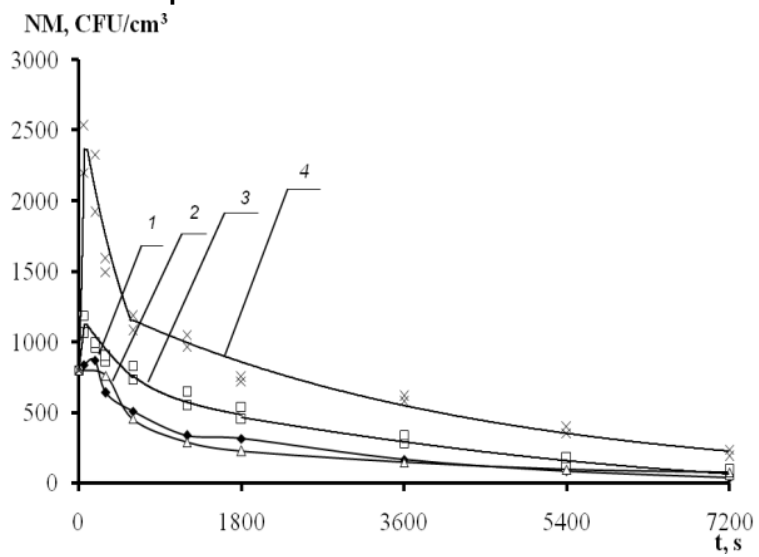

Figure 1: The change of NM values under the gas/US action: $\mathrm{Ar} / \mathrm{US}(1), \mathrm{O}_{2} / \mathrm{US}(2), \mathrm{He} / \mathrm{US}$ (3), $\mathrm{CO}_{2} / \mathrm{US}$ (4). Conditions: $\mathrm{NM}_{0}=8 \cdot 10^{2} \mathrm{CFU} / \mathrm{cm}^{3}, \mathrm{~T}=298 \pm 1 \mathrm{~K}$. 


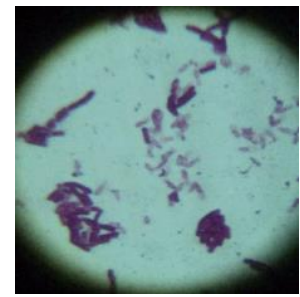

a)

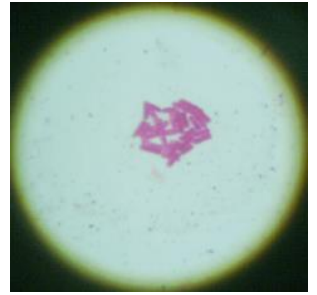

b)

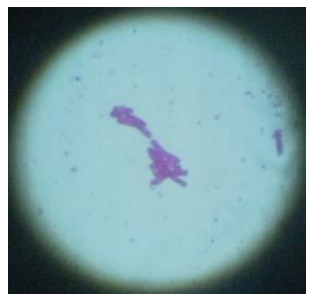

c)

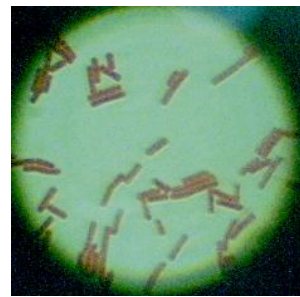

d)

Figure 2: Optical microscopy images of Bacillus before (a-c) and after (d) US exposure:

d) $\mathrm{t}=180 \mathrm{~s}$. Magnification of images is 1500 .

General destruction of cells has been observed during the second stage (until the duration of 7200 s) due to mechanical damage of outer cells membrane caused by cavitation action.

The processes, which are described above, occur independently of gas nature. But should be noted, that comparing the influence of different gases for water disinfection is not correctly in this case. It is connected with detection of disaggregation process, because $N M$ value at the action of different gas after disaggregation is substantially differ. But we are interested in some fact: how does the gas nature may affect the efficiency of cells disruption during sonication? Therefore, cells disruption but without microbial aggregates in the dispersion have been carried out further.

The dependence of $N M$ change of process time is presented on Fig. 3.

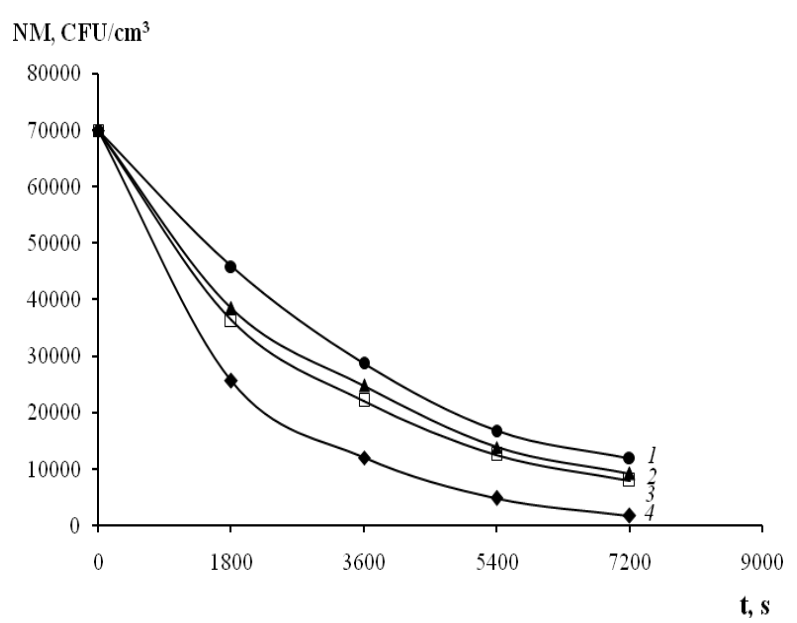

Figure 3: The change of NM values under the gas/US action: $\mathrm{CO}_{2} / \mathrm{US}(1), \mathrm{He} / \mathrm{US}(2), \mathrm{O}_{2} / \mathrm{US}$ (3), $\mathrm{Ar} / \mathrm{US}$ (4). Conditions: $\mathrm{NM}_{0}=7 \cdot 10^{4} \mathrm{CFU} / \mathrm{cm}^{3}, \mathrm{~T}=298 \pm 1 \mathrm{~K}$.

The kinetic regularities of microorganisms' destruction in the water system has been established. Fig. 4 represents a straight dependence of $N M / N M_{0}$ ratio of Bacillus destruction in a semi-logarithmic coordinates of kinetic reaction equation of the first order, of which were calculated the values of $k_{d}$ and correlation coefficients $\left(R_{d}\right)(T a b l e$ 2). 


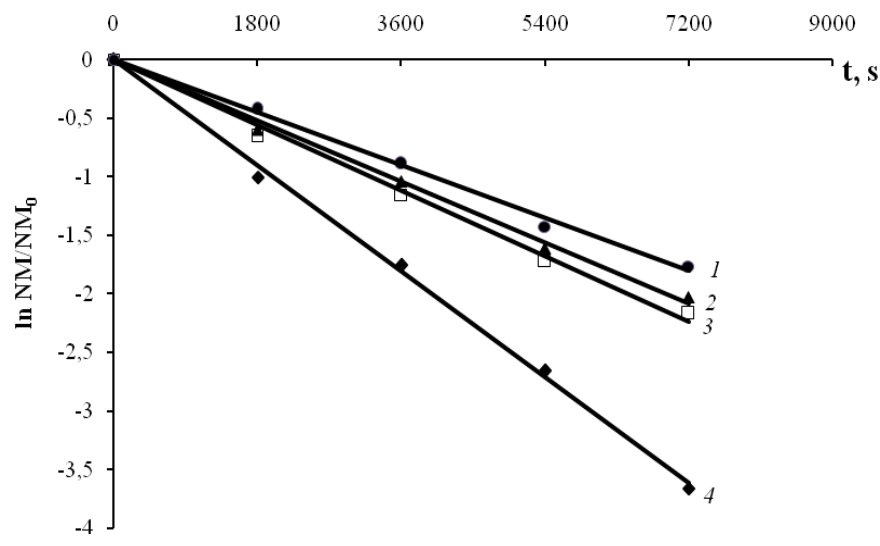

Figure 4: Semi-logarithmic dependences of the relative microorganism number on time: $\mathrm{CO}_{2} / \mathrm{US}(1), \mathrm{He} / \mathrm{US}(2), \mathrm{O}_{2} / \mathrm{US}(3), \mathrm{Ar} / \mathrm{US}(4)$.

Table 2

The effective rate constants of Bacillus destruction and degrees of the cell inactivation

\begin{tabular}{|c|c|c|c|}
\hline Conditions & $\mathbf{R}_{\mathrm{d}}$ & $\mathbf{k}_{\mathrm{d}} \cdot \mathbf{1 0}^{\mathbf{4}}, \mathbf{s}^{-\mathbf{1}}$ & $\mathbf{D}_{\mathrm{d}}, \boldsymbol{\%}$ \\
\hline $\mathbf{A r} / \mathbf{U S}$ & 0.998 & $5.02 \pm 0.03$ & 97.4 \\
\hline $\mathbf{O}_{2} / \mathbf{U S}$ & 0.994 & $3.11 \pm 0.06$ & 88.6 \\
\hline $\mathbf{H e} / \mathbf{U S}$ & 0.996 & $2.89 \pm 0.04$ & 86.9 \\
\hline $\mathbf{C O}_{2} / \mathbf{U S}$ & 0.996 & $2.51 \pm 0.04$ & 82.9 \\
\hline
\end{tabular}

In consequence, it can be determined in which gas atmosphere the process of Bacillus destruction is the most effective and it can be arranged in the following range:

\section{Ar/US $>\mathrm{O}_{2} / \mathrm{US}>\mathrm{He} / \mathrm{US}>\mathrm{CO}_{2} / \mathrm{US}$.}

Hence, it was established that sonication leads to the loss of reproductive ability of microbial cells and the most effective disruption of Bacillus bacteria type was carried out in the presence of argon in the US field.

\subsection{Oscillatoria brevis destruction}

Destruction of such microobjects as blue-green algae is a very actual issue in the water technology nowadays [6-8]. Prevention of excessive growth of cyanobacteria in the water is a problem of many countries, because of their massive development brings great harm of national management: the death of fish and waterfowl, poisoning animals and people, etc. [8]. Therefore, they have become the next object of our research. In addition, the US effect on the water purification from such cyanobacteria, which were defined in the investigated natural water has not been found in the literature.

According to the complex of morphological features of cyanobacteria, it was found that they are filamentous form, without heterocysts, trichomes consist only of the vegetative cells and form chains of cells, Gram-negative. Therefore, these cyanobacteria can be related to the Oscillatoria type (genius of $O$. brevis) from Oscillatoriaceae family (class Syanophyceae) (Fig. 5 a, b).

Microscoping samples of natural water after sonication were showed significant morphological changes of cyanobacteria: mechanical damage of outer shells with further allocation of internal filling of cells into the medium (Fig. $5 c, d$ ) and practically 
completely destroyed cells (Fig. $5 e, f$ ). Should be noted that sonicated cyanobacteria are not restored the cells in the water after the treatment.

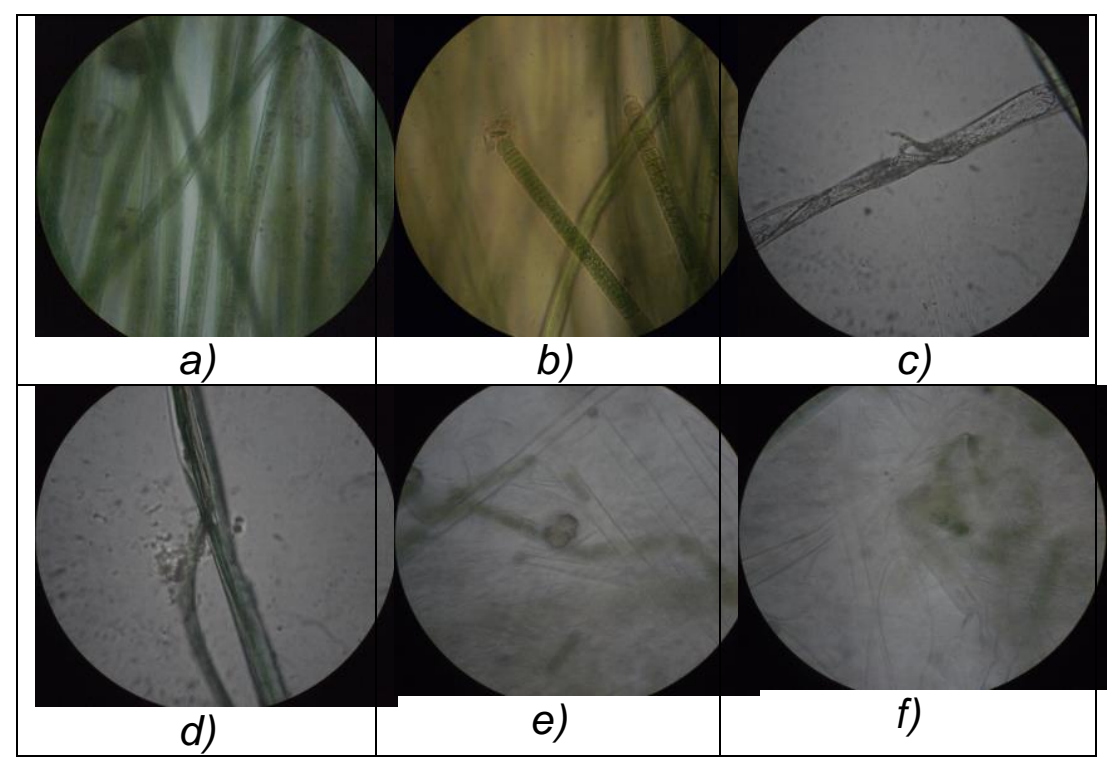

Figure 5: Optical microscopy images of Oscillatoria before $(a, b)$ and after $(c-f)$ US exposure: $c, d) \mathrm{t}=2-3 \mathrm{~s} ; e, f) \mathrm{t}=60 \mathrm{~s}$. Magnification of images is 600 .

The total duration of the process of cavitation treatment of this water was only 60 seconds. However, just as a result of a short-term exposure (2-3 seconds), on the optical microscopic images the mechanical damages of the membranes and the release of intracellular content into the liquid medium were observed; after 60 seconds exposure time, the completely destroyed cells were only found. This is manifested not only in the loss of their ability to physiological regeneration of cells and subsequent reproduction, but in almost complete cells destruction after US treatment.

\section{Conclusions}

In the present work, an effective cavitation action on the destruction of microorganisms and specific effect of sonication exposure on the different microobjects in the water medium have been established and next items were highlighted:

a) the high effectiveness of US action on the water disinfection from Bacillus and Oscillatoria cells has been achieved;

b) sonication enhances the breakup of the floc bacteria clumped together, thus they are more susceptible to the destruction;

c) water purification from microbial cells under the gas/US action corresponds to the kinetic regularities that are described by the reaction of the first order;

d) water disinfection depends on the nature of gas bubbling under cavitation conditions. The highest efficiency of water purification from Bacillus bacteria has been determined under the simultaneous action of argon and US;

e) sonicated B.cereus cells, similar to cyanobacteria of O.brevis, have lost their ability of physiological generation of the cells and reproduction ability after cavitational treatment; almost complete water disinfection has been achieved. 


\section{References}

[1] Antoniadis A., Poulios I., Nikolakaki E., Mantzavinos D. (2007) Sonochemical disinfection of municipal wastewater, J. Hazardous Mater, 146(3), 492-495.

[2] Zhang G., Zhang P., Wang B., Liu H. (2006) Ultrasonic frequency effects on the removal of Microcystis aeruginosa, Ultrasonics Sonochemystry, 13(5), 446-450.

[ 3 ] Koval I., Shevchuk L., Starchevskyy V. (2011) Ultrasonic intensification of the natural water and sewage disinfection, Chemical Engineering Transactions, 24(3), 1315-1320.

[4] Koval I. (2013) The pH variation of microbial suspension after gas bubbling and sonication, Chemistry \& Chemical Technology: Proceedings of the $3^{\text {th }}$ International Conference of Young Scientists CCT-2013, Lviv, 2013, 12-13.

[ 5 ] Koval I., Falyk T. (2016) Ultrasonic treatment of cells of investigated morphological and physiological features, $15^{\text {th }}$ International Scientific-Practical Conference "Resources of Natural Waters in Carpathian Region" (Problems of protection and rational exploitation), Lviv, 26-27 of May 2016, 92-95.

[ 6 ] Codd G.A., Oberemm A., Tarczyńska M. (2004) Recognition and awareness rising of toxic cyanobacterial blooms and associated poisonings at Lake Barlewice, Poland, in 1884 and recent cyanobacterial toxin analyses, Ecohydrology \& Hydrobiology, 4(1), 3-6.

[ 7 ] Kabziński A.K., Macioszek B.T., Szczukocki D.E., Juszczak R., Skowron W., Zawadzka A. (2005) Badania nad skutecznością usuwania mikrocystyny LR w układzie oczyszczania wody w Tomaszowie Mazowieckim, Ochr. Środ, 3, 39-42.

[ 8 ] Voloshko L., Kopecky J., Safronova T. (2008) Toxins and other bioactive compounds produced by cyanobacteria in Lake Ladoga, Estonian Journal of Ecology, 57(2), 100-110. 